\title{
Urinary paraquat concentration and white blood cell count as prognostic factors in paraquat poisoning
}

\author{
Qinliang $\mathrm{Xu}^{1,2}$, Xinli Wang ${ }^{2}$, Qiang $\mathrm{Wu}^{1}$, Xiangdong Jian ${ }^{1 \star}$, Baotian Kan ${ }^{1}$, Beijun \\ $\mathrm{GaO}^{1}$, Ke Wang ${ }^{1}$ \\ ${ }^{1}$ Departments of Poisoning and Occupational Diseases, Qilu Hospital, Shandong University, Jinan, Shandong 250012, \\ ${ }^{2}$ Emergency Department, Linyi People's Hospital, Shandong 276003, PR China
}

${ }^{*}$ For correspondence: Email: ih0713@163.com

\begin{abstract}
Purpose: To investigate the effect of white blood cell (WBC) and urinary paraquat ( $P Q$ ) levels on prognostic factors in patients exposed to $P Q$ intoxication using multivariate logistic regression analysis. Methods: A total of 104 subjects intoxicated with PQ between December 2015 and July 2016 were used in this retrospective study. They comprised patients who survived $(n=78)$, and patients who died $(n=26)$. Clinical features and prognostic parameters were analyzed in both groups. Multivariate logistic regression analysis was used to establish a prognostic correlation model based on results from single factor variables.

Results: Comparison of demographic and clinical attributes between the two groups, survivors $(n=78)$ and non-survivors $(n=26)$, revealed that those who survived were not as old (33.3 \pm 9.9 years) as nonsurvivors (41.5 \pm 12.9 years). In addition, on admission, it was found that the survivors ingested lower amounts of $P Q(31.6 \pm 13.8 \mathrm{ml})$ than non-survivors $(67.88 \pm 31.2 \mathrm{ml})$. There were significant differences between the two groups with respect to WBC, neutrophils, lymphocytes, lactate dehydrogenase $(L D H)$, creatine kinase (CK), amylase, uric acid (UA), pH, partial pressure of oxygen (PaO2), base excess (BE), lactic acid, and $D$-dimer levels $(p<0.05)$.

Conclusion: $W B C$ and urine $P Q$ concentration have strong correlation with prognostic factors in $P Q$ poisoning.
\end{abstract}

Keywords: Paraquat intoxication, Dithionite test, Multivariate logistic analysis, Prognosis, Predictors

\begin{abstract}
This is an Open Access article that uses a funding model which does not charge readers or their institutions for access and distributed under the terms of the Creative Commons Attribution License (http://creativecommons.org/licenses/by/4.0) and the Budapest Open Access Initiative (http://www.budapestopenaccessinitiative.org/read), which permit unrestricted use, distribution, and reproduction in any medium, provided the original work is properly credited.
\end{abstract}

Tropical Journal of Pharmaceutical Research is indexed by Science Citation Index (SciSearch), Scopus, International Pharmaceutical Abstract, Chemical Abstracts, Embase, Index Copernicus, EBSCO, African Index Medicus, JournalSeek, Journal Citation Reports/Science Edition, Directory of Open Access Journals (DOAJ), African Journal Online, Bioline International, Open-J-Gate and Pharmacy Abstracts

\section{INTRODUCTION}

Paraquat ( $P Q)$ is an active, rapid-action herbicidal agent used all over the world. Humans may ingest $P Q$ either by accident or deliberately through attempts at suicide, which may result in death [1]. This is so because ingested $P Q$ is extremely toxic.
Paraquat is environmentally harmless due to the fact that once it is in contact with the soil, it is rapidly decomposed to non-toxic compounds [2]. Unfortunately, it exerts extreme toxicity in man, with mortalities in the range of 50 to $90 \%$ [3]. In view of the high toxicity of this herbicide to humans, it is of concern that no effective 
treatments for $P Q$ poisoning have so far been developed [4]. Paraquat toxicity is a free radicalmediated process which results in oxidative stress and cellular apoptosis [5-9].

Studies on the immune-stimulatory potential of $P Q$ revealed that it enhances the expressions of CXL10, CXL11, and IL-10 (genes associated with inflammation) [10]. Since effective treatments for $P Q$ poisoning are not yet available, it is necessary to develop a method for predicting patient mortality. This is important because when unavoidable mortality is predicted timely, wrong treatment strategies can be discontinued in favor of more drastic remedies, especially when the $P Q$ intoxication is acute.

A number of prognostic factors have been proposed for predicting risks to patients with acute $P Q$ poisoning. Single laboratory analyses, such as serum $P Q$ concentration [11-13], arterial lactate [14], uric acid [15], lymphocyte and neutrophil counts, and creatinine [16] have been used in risk stratification. However, the level of $P Q$ in plasma, and the level of ingested $P Q$ are the most valid factors for predicting PQ-related fatalities [1,17]. Aside from the difficulty often encountered with accurate determination of ingested $P Q$, the assay facilities for serum $P Q$ are lacking in rural hospitals. Moreover, results from analysis of plasma $P Q$ concentration are not readily available in time in the hospital Emergency Departments (EDs). Plasma PQ level does not necessarily represent the ingested amount or the body burden of $P Q$, particularly when measured during the first few hours, because it peaks $1 \mathrm{~h}$ following ingestion, prior to a fast fall as it enters other body compartments [18].

Another potential indicator is the ingestion volume of $P Q$, which is difficult to calculate accurately, and even more difficult if postingestion vomiting occurred [19]. Therefore, prognostic factors that affect survival of patients with $P Q$ poisoning were investigated in the present study with a view to predicting the probability of survival through the initial laboratory findings at the point of hospital admission.

\section{METHODS}

This study is a retrospective cohort investigation based on observation of subjects admitted at ED ward of Qilu Hospital, Shandong Province between December 2015 and July 2016. A total of 104 patients who ingested $P Q$ were enrolled initially for further selection. The exclusion criteria were: (a) weak or negative urine dithionite test
(23 patients); (b) evidence of hemo-perfusion prior to hospital admission more than $24 \mathrm{~h}$ after $P Q$ ingestion (103 patients); (c) PQ poisoning by routes other than ingestion (15 patients); (d) pregnant or lactating patients; (e) patients with cardiac arrest after $P Q$ poisoning $(n=9)$; $(\mathrm{f})$ medical history of pancreatic, heart, liver, kidney, or central nervous system disease, and/or refusal of consent (7 patients); and inability to obtain APACHE2 score after admission. Included subjects were assigned to 2 groups i.e. survivors and non-survivors), and their initial laboratory data were compared and analyzed. This work was approved by the Ethical Committee of Qilu Hospital (approval no. 201707832) and complied with the guidelines of Declaration of Helsinki promulgated in 1964 as amended in 1996 [20].

On admission, all patients received standardized medical emergency treatments. These included methylprednisolone administration at decreasing doses in response to improvements in patients' status; myocardial nutrition, complete lavage of the gastrointestinal tract, hemo-perfusion, protection of the liver, gastrointestinal mucosa and the kidneys; ROS neutralization, and ensuring water and electrolyte homeostasis by administering the Qilu scheme of the Department of Poisoning and Occupational Diseases [21].

On arrival, each patient's urinary $P Q$ was checked semi-quantitatively by the doctor on duty, using the dithionite method. The results of urinary PQ test were recorded as Grades 1 - 4 by comparison with a standard color card viz: $<10$ $\mu \mathrm{g} / \mathrm{mL}$ = black; $10-30 \mu \mathrm{g} / \mathrm{mL}=$ deep blue; $30-$ $100 \mu \mathrm{g} / \mathrm{mL}=$ light blue, and $>100 \mu \mathrm{g} / \mathrm{mL}=$ barely discernable blue. The genders and ages of the subjects were recorded, as well as the lag in time between admission and exposure to $P Q$, in addition to vital signs. Laboratory results on hematological parameters such as WBC count, lymphocyte count and neutrophil count were compiled, in addition to patient data on arterial blood $\mathrm{pH}$, base excess (BE), $\mathrm{Pa}_{\mathrm{O} 2}, \mathrm{~Pa}_{\mathrm{CO} 2}$, base excess (BE), level of $P Q$ in plasma, and BUN. Other records obtained included plasma potassium and sodium levels, total bilirubin (TBil), lactate dehydrogenase (LDH), creatine kinase (CK), glutamate pyruvate transaminase (AST), glutamate pyruvate transaminase (ALT), D-dimer, blood glucose, and uric acid (UA). This investigation was hinged on mortality within thirty days of hospital presentation. Thus, if a subject got discharged during this time frame, efforts were made to determine whether they took part in follow up as outpatients, and regular contact was made with them through telephone interview. 


\section{Statistical analysis}

Continuous variable data are presented as mean \pm standard deviation (SD), and compared between survivors and non-survivors using Mann-Whitney test. Categorical variable data are presented as frequency (\%), and compared between the two groups using Fisher's exact test or chi square test. Mortality determinants were identified using multivariate logistic stepwise regression analysis, and expressed in terms of odds ratios (ORs) with $95 \% \mathrm{Cl}$. All analyses were carried out with SPSS 13.0. Statistical significance was fixed at $p<0.05$.

\section{RESULTS}

\section{Baseline features of subjects}

Sixty (60) of the study participants were males $(57.7 \%)$. On the average, the time lag from $P Q$ intake to hospital admission was $6.4 \mathrm{~h}$. Comparison of demographic and clinical features between the two groups showed that those who survived were significantly younger in age (33.3 \pm 9.9 years, in contrast to $41.5 \pm 12.9$ years for non-survivors, $p=0.049$ ), and ingested significantly lower $P Q$ as seen on admission $(31.6 \pm 13.8 \mathrm{~mL}$ in contrast to $67.88 \pm 31.2 \mathrm{~mL}$ in non-survivors, $p=0.001$ ). However, there were no differences in gender and time lag before $P Q$ ingestion and hospitalization between the 2 groups $(p=0.670)$. These results are shown in Table 1.

Table 1: Clinical and demographic features of subjects

\begin{tabular}{|c|c|c|c|}
\hline Parameter & $\begin{array}{l}\text { Subjects } \\
\text { alive } \\
(n=78)\end{array}$ & $\begin{array}{c}\text { Dead } \\
\text { subjects } \\
(n=26)\end{array}$ & $\begin{array}{c}p \\
\text { value }\end{array}$ \\
\hline Male/Female & $52 / 26$ & $18 / 8$ & 0.073 \\
\hline Age (years) & $33.3 \pm 9.9$ & $41.5 \pm 12.9$ & 0.049 \\
\hline $\begin{array}{l}\text { Amount of PQ } \\
\text { ingested }(\mathrm{mL})\end{array}$ & $31.6 \pm 13.8$ & $67.8 \pm 31.2$ & 0.001 \\
\hline $\begin{array}{l}\text { Time lag } \\
\text { before } \\
\text { hospital } \\
\text { admission (h) }\end{array}$ & $6.1 \pm 5.0$ & $7.2 \pm 3.9$ & 0.670 \\
\hline
\end{tabular}

\section{Clinical features of dead and live subjects}

The results in Table 2 show that the initial laboratory data on WBC, neutrophils, lymphocytes, $\mathrm{LDH}, \mathrm{CK}, \mathrm{UA}, \mathrm{pH}, \mathrm{Pa}_{\mathrm{CO} 2}$, $\mathrm{BE}$, lactic acid, and D-dimer differed significantly $(p<0.05)$ between survivors and non-survivors. The proportion of +ve or strongly +ve urine dithionite test results was larger in non-survivors than in survivors.
Table 2: Initial laboratory data at point of admission

\begin{tabular}{|c|c|c|c|}
\hline Variable & $\begin{array}{c}\text { Survivors } \\
(n=78)\end{array}$ & $\begin{array}{c}\text { Non- } \\
\text { survivors } \\
(\mathrm{n}=26)\end{array}$ & $P$-value \\
\hline Urine $P Q$ & $\mathrm{n}(\%)$ & $\mathrm{n}(\%)$ & - \\
\hline$<10 \mu \mathrm{g} / \mathrm{ml}$ & $20(25.6)$ & 0 & - \\
\hline $10-30 \mu \mathrm{g} / \mathrm{ml}$ & $18(23.1)$ & 0 & - \\
\hline $30-100 \mu \mathrm{g} / \mathrm{ml}$ & $34(43.6)$ & $2(7.7)$ & - \\
\hline$>100 \mu \mathrm{g} / \mathrm{ml}$ & $6(7.7)$ & 24 (92.3) & $<0.001$ \\
\hline WBC $\left(10^{9} / \mathrm{L}\right)$ & $9.71(4.2)$ & $22.9 \pm 7.7$ & $<0.001$ \\
\hline $\begin{array}{l}\text { Neutrophils } \\
\left(10^{9} / \mathrm{L}\right)\end{array}$ & $7.63(3.7)$ & $20.6 \pm 7.6$ & $<0.001$ \\
\hline $\begin{array}{l}\text { Lymphocytes } \\
\left(10^{9} / \mathrm{L}\right)\end{array}$ & $1.3 \pm 0.6$ & $0.47(0.7)$ & 0.038 \\
\hline ALT (ÚL) & $27(21)$ & $18(16)$ & 0.305 \\
\hline AST (U/L) & 29 (14) & $46(83)$ & 0.060 \\
\hline TBil & 14 (12) & $17(8)$ & 0.156 \\
\hline BUN & $5.2 \pm 1.5$ & $4.9(5.0)$ & 0.336 \\
\hline $\mathrm{Cr}$ & $66(23)$ & $\begin{array}{c}121.0 \pm \\
67.3\end{array}$ & 0.063 \\
\hline $\mathrm{LDH}(\mathrm{U} / \mathrm{L})$ & $\begin{array}{c}201.8 \pm \\
56.1\end{array}$ & $\begin{array}{c}233.0 \pm \\
43.2\end{array}$ & 0.006 \\
\hline CK (U/L) & $\begin{array}{c}122.3 \pm \\
51.2\end{array}$ & $\begin{array}{c}140.0 \pm \\
62.4\end{array}$ & 0.023 \\
\hline $\mathrm{K}(\mathrm{mEq} / \mathrm{L})$ & $3.7 \pm 0.3$ & $2.9 \pm 0.4$ & $<0.001$ \\
\hline $\begin{array}{l}\text { Amylase } \\
\text { (IU/L) }\end{array}$ & $74(92)$ & $176(370)$ & $<0.001$ \\
\hline $\mathrm{UA}(\mu \mathrm{mol} / \mathrm{L})$ & $\begin{array}{c}320.0 \pm \\
81.0\end{array}$ & 390 (104) & 0.049 \\
\hline $\mathrm{PH}$ & $7.42 \pm 0.03$ & $7.35 \pm 0.1$ & 0.04 \\
\hline $\begin{array}{l}\mathrm{PacO} 2 \\
(\mathrm{mmHg})\end{array}$ & $35.2 \pm 3.7$ & $25.2 \pm 4.2$ & $<0.001$ \\
\hline $\mathrm{BE}(\mathrm{mEq} / \mathrm{L})$ & $0.8(1.9)$ & $-8.9 \pm 5.6$ & $<0.001$ \\
\hline $\begin{array}{l}\text { Lactic acid } \\
\text { (mEq/L) }\end{array}$ & $1.6(1.0)$ & $7.5(10.2)$ & $<0.001$ \\
\hline Blood glucose & $6.5(1.9)$ & $7.5 \pm 1.2$ & 0.074 \\
\hline D-dimer & $0.29(0.36)$ & $\begin{array}{c}0.48 \\
(0.35) \\
\end{array}$ & 0.047 \\
\hline
\end{tabular}

\section{Univariate logistic regression}

Results of univariate logistic regression analysis carried out to select the predictors of death from PQ poisoning showed that 13 predictors had $p$ values lower than 0.05 (Table 3).

\section{Multivariate logistic regression analysis}

Arising from the results of univariate logistic analysis, multivariate logistic stepwise regression analysis was carried out. The results showed that WBC and urine $P Q$ concentration had strong correlations with prognosis-related factors in $\mathrm{PQ}$ intoxication in accordance with the equation:

Logit $(P / 1-P)=0.088[$ urine $P Q]+0.267[W B C]$ 11.742 ......... (1)

This relationship is useful in predicting survival of persons exposed to acute PQ intoxication. 
Table 3: Univariate logistic regression data

\begin{tabular}{|c|c|c|c|}
\hline Variable & $\begin{array}{c}p \\
\text { value }\end{array}$ & OR & $95 \% \mathrm{Cl}$ for OR \\
\hline WBC $\left(10^{9} / \mathrm{L}\right)$ & 0.001 & 1.341 & $1.133-1.588$ \\
\hline \multirow{2}{*}{$\begin{array}{l}\text { Neutrophils } \\
\left(10^{9} / \mathrm{L}\right) \\
\text { Lymphocytes } \\
\left(10^{9} / \mathrm{L}\right)\end{array}$} & $\begin{array}{c}< \\
0.001\end{array}$ & 1.322 & 1.1251 .554 \\
\hline & 0.656 & 0.868 & 0.4661 .618 \\
\hline $\mathrm{ALT}(\mathrm{U} / \mathrm{L})$ & 0.719 & 0.994 & 0.9591 .029 \\
\hline $\begin{array}{l}\text { AST (U/L) } \\
\text { TBil }\end{array}$ & $\begin{array}{l}0.011 \\
0.191\end{array}$ & $\begin{array}{l}1.037 \\
1.036\end{array}$ & $\begin{array}{l}1.0091 .066 \\
0.9831 .093\end{array}$ \\
\hline BUN & 0.067 & 1.191 & 0.9881 .437 \\
\hline $\begin{array}{l}\mathrm{Cr} \\
\mathrm{LDH}(\mathrm{U} / \mathrm{L})\end{array}$ & $\begin{array}{l}0.014 \\
0.001\end{array}$ & $\begin{array}{l}1.019 \\
1.003\end{array}$ & $\begin{array}{l}1.0041 .034 \\
1.0021 .004\end{array}$ \\
\hline $\mathrm{CK}(\mathrm{U} / \mathrm{L})$ & 0.002 & 1.000 & 1.0001 .001 \\
\hline $\begin{array}{l}\text { Potassium } \\
\text { (mEq/L) }\end{array}$ & 0.001 & 0.024 & 0.003 \\
\hline Amylase (IU/L) & 0.003 & 1.009 & 1.0031 .016 \\
\hline $\mathrm{UA}(\mu \mathrm{mol} / \mathrm{L})$ & 0.035 & 1.008 & 1.0011 .016 \\
\hline $\mathrm{pH}$ & 0.007 & $0 \stackrel{<}{001}$ & 0.017 \\
\hline $\begin{array}{l}\mathrm{pCO} 2(\mathrm{mmHg}) \\
\mathrm{BE}(\mathrm{mEg} / \mathrm{L})\end{array}$ & $\begin{array}{l}0.001 \\
0.001\end{array}$ & $\begin{array}{l}0.687 \\
0.680\end{array}$ & $\begin{array}{ll}0.553 & 0.852 \\
0.545 & 0.850\end{array}$ \\
\hline $\begin{array}{l}\text { Lactic acid } \\
\text { (mEq/L) }\end{array}$ & 0.002 & 1.459 & 1.1521 .847 \\
\hline Blood glucose & 0.403 & 1.124 & 0.8541 .480 \\
\hline D-dimer & 0.185 & 2.982 & 0.59315 .005 \\
\hline
\end{tabular}

\section{DISCUSSION}

The plasma levels of $P Q$ are of prognostic value in patients exposed to acute $P Q$ intoxication. Indeed, data on changes in plasma PQ levels with time have been applied in the prediction of prognosis in PQ-poisoned patients for several years [3]. Recently, the bio-markers lipocalin and pentraxin have been used for predicting survival in patients poisoned with $P Q[22,23]$. However, these predictors were derived from smallpopulation studies, and they predict mortality rather than revival [24]. The present study has revealed that WBC is an independent prognostic factor in $P Q$ intoxication. The link between $P Q$ exposure, WBC levels, and 30-day mortality is unclear. It is possible that $P Q$ poisoning induces immune-stimulation which results in increased levels of WBC. This may explain the high prognostic potential of WBC with respect to prediction of 30-day mortality after PQ ingestion, which is considered a very important finding in the present study.

The volume of ingested $P Q$ was determined on the basis of adult mouthful swallow, with a mean volume of approximately $20 \mathrm{~mL}$, which is in agreement with previous reports [25-27]. However, in some instances, the precise amount of $P Q$ ingested could not be confirmed especially for subjects who got exposed to $P Q$ by drinking from a bowl, cup or glass. Moreover, due to alcohol bemusement or an upset state of mind at the point of exposure, some subjects were unable to recall the volume of $P Q$ consumed or the exact time of exposure to $P Q$ [28-30]. However, these lapses are less significant than problems associated with interpreting data from blood $P Q$ profiles which change appreciably with time lag after $P Q$ intake $[31,32]$. Therefore, a more correct and authentic index for prediction of outcomes of $P Q$ poisoning is urinary dithionite test. Moreover, it is easy to carry out, and the reagents are readily available, especially in the grass-root hospitals.

\section{Study limitations}

This study has some limitations. Being retrospective in nature, and due to the use of a semi-quantitative method for determination of urinary $P Q$ concentration, it was not possible to draw ROC curve. Thus, the results of this study can only support the theory of conclusions on correlation through the multifactor analysis. Moreover, the study focused only on laboratory examination, which limits its significance. The clinical significance of the findings would have been enhanced by analyzing them with APACHE II scores.

\section{CONCLUSION}

The results obtained in this study demonstrate that initial clinical laboratory data are very crucial for assessing the outcome of $P Q$ poisoning. In particular, WBC and urine $P Q$ concentration have strong correlation with prognostic factors in $P Q$ intoxication, and are useful for predicting survival in acute $P Q$-intoxicated patients.

Table 4: Multivariate logistic regression data

\begin{tabular}{lccccccc}
\hline \multirow{2}{*}{ Index } & Coefficient & \multirow{2}{*}{ Standard error } & \multirow{2}{*}{ Wald } & \multirow{2}{*}{$\boldsymbol{p}$ value } & \multirow{2}{*}{ OR } & \multicolumn{2}{c}{$\mathbf{9 5} \% \mathbf{C l}$} \\
\cline { 5 - 8 } & & & & & & Lower & Upper \\
\hline Urine PQ & 0.088 & 0.040 & 4.909 & 0.027 & 1.092 & 1.010 & 1.181 \\
WBC & 0.267 & 0.108 & 6.143 & 0.013 & 1.307 & 1.058 & 1.614 \\
Constant term & -11.742 & 4.779 & 6.037 & 0.014 & 0.000 & & \\
\hline
\end{tabular}




\section{DECLARATIONS}

\section{Acknowledgement}

This study was supported by National Key Clinical Specialty (no. 2012650) and the Taishan Scholar Program of Shandong Province (no. ts20130911).

\section{Conflict of interest}

No conflict of interest is associated with this study.

\section{Contribution of authors}

We declare that this work was done by the author(s) named in this article and all liabilities pertaining to claims relating to the content of this article will be borne by the authors. All authors read and approved the manuscript for publication. Xiangdong Jian conceived and designed the study. Xinli Wang, Qiang Wu, Baotian Kan, Beijun Gao and Ke Wang collected and analysed the data, while Qinliang Xu wrote the manuscript.

\section{REFERENCES}

1. Jeyaratnam J. Acute pesticide poisoning: a major global health care problem. World Health Stat Q 1990; 43: 139144.

2. Senarathna L, Eddleston $M$, Wilks MF, Woollen $B H$, Tomenson JA, et al. Prediction of outcome after paraquat poisoning by measurement of the plasma paraquat concentration. QJM 2009; 102: 251-259.

3. Dinis-Oliveira RJ, Duarte JA, Sanchez-Navarro A, Remi ao F, Bastos ML, Carvalho F. Paraquat poisonings: mechanisms of lung toxicity, clinical features, and treatment. Crit Rev Toxicol 2008; 38: 13-71.

4. Jones GM, Vale JA. Mechanisms of toxicity, clinical features, and management of diquat poisoning: a review. J Toxicol Clin Toxicol 2008; 38: 123-128.

5. Mohammadi-Bardbori A, Ghazi-Khansari M. Alternative electron acceptors: Proposed mechanism of paraquat mitochondrial toxicity. Environ Toxicol Pharmacol 2008; 26: 1-5.

6. Blanco-Ayala $T$, Ande 'rica-Romero AC, PedrazaChaverri J. New insights into antioxidant strategies against paraquat toxicity. Free Radic Res 2014; 48 : 623-640.

7. Han J, et al. Betanin attenuates paraquat-induced liver toxicity through a mitochondrial pathway. Food Chem Toxicol 2014; 70: 100-106.

8. Dinis-Oliveira RJ, Duarte JA, Sa'nchez-Navarro A, Remia o F, Bastos ML, et al. Paraquat Poisonings: Mechanisms of Lung Toxicity, Clinical Features, and Treatment. Crit Rev Toxicol 2008; 38: 13-71.
9. Suntres ZE. Role of antioxidants in paraquat toxicity. Toxicol 2002; 180: 65-77.

10. Paolillo N, Piccirilli S, Giardina E, Rispoli V, Colica C, et al. Effects of paraquat and capsaicin on the expression of genes related to inflammatory, immune responses and cell death in immortalized human HaCat keratinocytes. Int J Immunopathol Pharmacol 2011; 24: 861-868.

11. Gil HW, Kang MS, Yang JO, Lee EY, Hong SY. Association between plasma paraquat level and outcome of paraquat poisoning in 375 paraquat poisoning patients. Clin Toxicol (Phila) 2008; 46: 515518.

12. Scherrmann JM, Houze $P$, Bismuth $C$, Bourdon $R$. Prognostic value of plasma and urine paraquat concentration. Hum Toxicol 1987; 6: 91-93.

13. Senarathna $L$, et al. Prediction of outcome after paraquat poisoning by measurement of the plasma paraquat concentration. QJM 2009; 102: 251-259.

14. Lee $Y$, et al. Arterial lactate as a predictor of mortality in emergency department patients with paraquat intoxication. Clin Toxicol (Phila) 2012; 50: 52-56.

15. Zhang J, et al. The significance of serum uric acid level in humans with acute paraquat poisoning. Sci Rep 2015; 5: 9168.

16. Kang $C$, et al. Absolute lymphocyte count as a predictor of mortality in emergency department patients with paraquat poisoning. PLoS One 2013; 8: e78160.

17. Lee $E Y$, Hwang $K Y$, Yang J-O, Hong SY. Predictors of survival after acute paraquat poisoning. Toxicol Ind Health 2002; 18: 201-206.

18. Houzé P, Baud FJ, Mouy R, Bismuth C, Bourdon R, Scherrmann JM. Toxicokinetics of paraquat in humans. Hum Exp Toxicol 1990; 9: 5-12.

19. Hart TB, Nevitt A, Whitehead A. A new statistical approach to the prognostic significance of plasma paraquat concentrations. Lancet 1984; 2: 1222-1223.

20. World Health Organization. Declaration of Helsinki. Br Med J 1996; 313(7070): 1448-1449.

21. Jian $X$, Zhang $H$, Sui $H$, Guo G, et al. Qilu Scheme of $P Q$ poisoning treatment. Chin J Ind Med 2014; 27: 119-121. (In Chinese).

22. Yeo CD, Kim JW, Kim YO, Yoon SA, Kim KH, Kim YS. The role of pentraxin-3 as a prognostic biomarker in paraquat poisoning. Toxicol Lett 2012; 20: 157-160.

23. Wunnapuk K, Liu X, Peake P, Gobe G, Endre Z, Grice JE, Roberts MS, Buckley NA. Renal biomarkers predict nephrotoxicity after paraquat. Toxicol Lett 2013; 222: 280-288.

24. Senarathna L, Eddleston M, Wilks MF, Woollen $B H$, Tomenson JA, Roberts DM, Buckley NA. Prediction of outcome after paraquat poisoning by measurement of the plasma paraquat concentration. QJM 2009; 102: 251-259.

25. Kim YT, Jou SS, Lee HS, Gil HW, Yang JO, Lee EY, Hong SY. The area of ground glass opacities of the lungs as a predictive factor in acute paraquat intoxication. J Korean Med Sci 2009; 24: 636-640. 
26. Kim SJ, Gil HW, Yang JO, Lee EY, Hong SY. The clinical features of acute kidney injury in patients with acute paraquat intoxication. Nephrol Dial Transplant 2009; 24: 1226-1232.

27. Gil HW, Yang JO, Lee EY, Hong SY. Clinical implication of urinary neutrophil gelatinase-associated lipocalin and kidney injury molecule-1 in patients with acute paraquat intoxication. Clin Toxicol (Phila) 2009; 47: 870-875.28.

28. Kang C, Kim SC, Lee SH, Jeong JH, Kim DS, Kim DH. Absolute lymphocyte count as a predictor of mortality in emergency department patients with paraquat poisoning. PLoS One 2013; 8: e78160.

29. In OS, Sung HS, Hyun JY, Kwang YL. Predicting the probability of survival in acute paraquat poisoning. Kidney Res Clin Pract 2016; 35:102-106.
30. Zhang J, Zhao Y, Bai Y, Lv G, Wu J, Chen Y. The significance of serum uric acid level in humans with acute paraquat poisoning. Sci Rep 2015; 5: 9168.

31. Sujin S, Young-hee K, Hyo-wook G, Ho-yeon S, Saeyong $H$. The Time between Paraquat Ingestion and a Negative Dithionite Urine Test in an Independent Risk Factor for Death and Organ Failure in Acute Paraquat Intoxication. J Korean Med Sci 2012; 27: 993-998. [cited 2018 June 8]. Available from: http://synapse.koreamed.org/DOlx.php?id=10.3346/jkms .2012.27.9.993

32. Yi L, Meng W, Yanxia G, Wen Y, Qun X, Michael E, Li L, Xuezhong $Y$. Abnormal pancreatic enzymes and their prognostic role after acute paraquat poisoning. Sci Rep 2015; 5: 17299. 